\title{
The Modern Streetcar in the U.S.: An Examination of Its Ridership, Performance, and Function as a Public Transportation Mode
}

Jeffrey Brown, Florida State University

\begin{abstract}
Seven U.S. cities reported operating streetcar service to the National Transit Database in 2012, and many other cities are building or planning streetcar investments. Yet despite the increased popularity of streetcar investments, there is a lack of information about how these investments function as transportation modes, as opposed to urban development tools. This paper examines the streetcar as a public transit mode by examining ridership, service, service productivity, cost effectiveness, and other indicators of the streetcar's performance and function in the carriage of transit passengers. There is considerable variation in all of these measures, with the variability a function of the different environments in which streetcars operate, the different roles they play in the local transit system, and differences in the operating characteristics of the streetcars themselves. Among the cases, Portland's streetcar emerges as a strong performer, Little Rock's and Tampa's streetcars as relatively poor performers, and the other streetcars have mixed performance results.
\end{abstract}

\section{Introduction}

The streetcar, an urban transportation mode whose golden age was thought to have been the period from roughly the 1890 s to the 1910s, has made a remarkable resurgence in the United States in recent years. As of September 2012, transit 
agencies in eight cities reported operating streetcar modes in regular, year-round revenue service to the Federal Transit Administration (FTA): Little Rock, Memphis, New Orleans, Philadelphia, Portland, Seattle, Tacoma, and Tampa (Federal Transit Administration [FTA] 2012). Boston and San Francisco also operate streetcars on their Ashmont-Mattapan and $F$ lines, respectively, although their statistics are folded into their light rail transit (LRT) services in the National Transit Database (NTD) statistics. Several other cities, from Kenosha, Wisconsin, to San Pedro, California, operate seasonal or weekend-only streetcar lines. Several cities report streetcar projects under construction, while more than 40 others have projects in various stages of planning. The streetcar's apparent rebirth after decades of what had appeared to have been technological obsolescence is truly remarkable.

There are many reasons for the streetcar's return to the urban transportation scene, although economic development and the availability of federal capital funding under the New Starts/Small Starts program are the most frequently cited rationales for its reemergence (Scheib 2012; Transit Cooperative Research Program [TCRP] 2010). Both streetcar supporters and streetcar critics point to Portland, Oregon, to support their assertions about the streetcar's urban development effects. Supporters point to hundreds of millions of dollars in commercial development and redevelopment, particularly in the city's Pearl District (Hovee and Gustafson 2012; TCRP 2010), which they argue can be traced directly to Portland's decision to build a streetcar; skeptics argue that public financial incentives and regulatory inducements were more important than the streetcar itself in attracting development to these locations (O'Toole 2012; Scheib 2012). The real explanation for Portland's apparent redevelopment success is most likely a combination of these factors, combined with a desirable location and a vibrant local real estate market. The relative abundance of federal capital funding under the Small Starts program for streetcar development and the relative lack of federal funding for more expensive conventional LRT development has also encouraged cities to look to streetcars instead of other rail modes when they consider making significant fixed transit investments. Officials in the Obama Administration have been especially strong promoters of streetcar development.

This paper does not attempt to explain the streetcar's role in the urban development and redevelopment process, nor does it offer suggestions for the future of federal transit capital grants policy. Instead, it sets a much narrower, but still important, task-it explores a much-neglected aspect of the streetcar's rebirth in the modern metropolis, namely its role as a means of transportation situated within a 
local public transit system. The streetcar is fundamentally a transportation technology, but the scholarly and practitioner literature that considers the streetcar as primarily a public transportation mode, as opposed to an urban development tool, is remarkably sparse. Indeed, the only published work this author could find that took a ridership and operations approach to examining streetcars was a graduate student client project for a transit agency that examined four streetcar cities in the context of an alternatives analysis dealing with streetcars, light rail transit, and French tramways (Transit Alternatives Studio Members 2011). The author found that streetcars were not as efficient or cost-effective in carrying riders than either of the other two rail technologies. While a very worthy reference, the work takes a necessarily circumscribed approach to the streetcar discussion by virtue of its broader topical focus on an array of rail modes. This paper is an attempt to begin to remedy the lack of ridership and operation-oriented empirical work on streetcars. It does so by examining the streetcar in terms of its ridership, its service performance statistics, and its level of integration with and role within the larger transit system in the community. The paper explores the streetcar's performance and role as a public transportation mode by looking at seven of the eight cities that report operating year-round, regular revenue streetcar service in the NTD. These seven cities include six cities whose streetcar lines are 20 years old or newer (Little Rock, Memphis, Portland, Seattle, Tacoma, and Tampa) and one city (New Orleans) whose lines predate the streetcar's modern reemergence. Among these seven cities, there is significant variation in streetcar ridership and performance, with the variation a function of both the way the streetcar is either integrated (or not) with the rest of the transit system, its operating characteristics, and the nature of the built environment within which the streetcar operates. The paper closes with lessons from these cases and directions for future research.

\section{Seven Streetcar Cases}

Seven cities were selected for inclusion in the analysis, by first considering all the transit agencies that reported operating a streetcar mode to the NTD and then narrowing this list based on the regularity of the service being operated and the availability of streetcar data preceding the 2012 reporting year when the NTD separated streetcar (mode code SR) from light rail (mode code LR) service in the database. These criteria led to the exclusion of two of the nine cities that reported streetcar service to the NTD in 2012: Kenosha on the basis of its seasonal service provision and Philadelphia due to data availability concerns, as streetcar data are not separated from the Southeastern Pennsylvania Transportation Author- 
ity's light rail services prior to the 2012 NTD reporting year. The research did not consider Boston or San Francisco because the Massachusetts Bay Transportation Authority and San Francisco Municipal Transportation Agency continue to report their streetcar line statistics to the NTD as part of their light rail statistics. Little Rock, Memphis, New Orleans, Portland, Seattle, Tacoma, and Tampa emerged as the case study cities for the investigation.

The investigation began with several questions in mind. First, what are the basic characteristics of the streetcars and how do they differ? Second, how many riders do they carry, how productively, and at what cost? And, third, where do the streetcars fit in, if at all, with the rest of the transit system? A combination of ridership, service, and cost data were obtained from the NTD, plus internal data were obtained from each agency to address each of these questions. Before answering these questions, each of the seven streetcar cases is briefly described below.

\section{Little Rock}

Little Rock's streetcar, River Rail, connects the downtowns of Little Rock and North Little Rock using an alignment that is mixed traffic except for a dedicated lane on a bridge over the Arkansas River (Central Arkansas Transit Authority 2012; Smatlak 2012). The streetcar consists of a Blue line that connects the two downtowns and a Green line that operates through downtown Little Rock. The original line opened in 2004, and an extension opened in 2007. The River Rail functions as a circulator connecting major downtown destinations, including the Clinton Presidential Library.

\section{Memphis}

Memphis's streetcar, the Trolley, consists of the Main Street line (opened in 1993), the Riverfront line (opened in 1997), and the Madison Avenue line (opened in 2004) (Memphis Area Transit Authority 2012; Smatlak 2012). The first two lines operate in the downtown area and along the Mississippi River, with the Main Street line operating in mixed traffic, except for the segment through the Main Street pedestrian mall, and the Riverfront line operating on a dedicated, double-track railroad right-of-way near the river. The Madison Avenue line operates in mixed traffic. The older lines connect important destinations in the downtown area, with the Riverfront line functioning as a belt-like circulator through the downtown area. The Madison Avenue line connects the downtown lines with important destinations to the east, include major medical facilities. 


\section{New Orleans}

New Orleans operates three streetcar lines, one of which (Canal Street) has two branches (New Orleans Regional Transportation Authority 2012; Smatlak 2012). The oldest line, St. Charles, dates to the late 19th century. The line operates primarily in a center median, except for a short distance in mixed-traffic service. This line has more than 50 stops and is operated 24 hours a day, 7 days a week. The Riverfront line, which dates back to 1988, uses a traditional railroad right-of-way, serving major tourist-related destinations including areas near the French Quarter and commercial development in the Warehouse and Riverfront districts. The Canal Street line, restored to streetcar service in 1999 , operates in a center median and features stops every two blocks. Much of the line operates through the downtown area. The branch lines include some mixed-traffic operation.

\section{Portland}

Portland now operates both a north-south and a central loop line (just opened), but this study focuses on the original north-south line (opened in 2001) that connects the Pearl District, Downtown, and Portland State University and operates as a one-way circulator loop primarily on parallel city streets (Portland Streetcar, Inc. 2012a; Smatlak 2012). The area consists of very high-density development, with many observers pointing to the streetcar as an important contributor to recent redevelopment activity. The recently-opened central loop line operates on both sides of the Willamette River and provides links between the downtown core and the eastside Lloyd Center area and the eastside central industrial district.

\section{Seattle}

Seattle's South Lake Union streetcar (opened in 2007) connects the South Lake Union neighborhood to downtown via Westlake and Terry Avenues (Seattle Streetcar 2012; Smatlak 2012). There has been much employment growth in this corridor in recent years. The streetcar operates both in mixed traffic and in a dedicated lane through portions of the alignment.

\section{Tacoma}

Tacoma's streetcar, Tacoma Link, operates in the downtown area and as a feeder to the longer-distance bus and regional rail services at its terminal station (Sound Transit 2012; Smatlak 2012). The line operates in a combination of center-median and reserved-lane alignments over its short alignment. The Tacoma streetcar is a fare-fee system. The transit agency brands the line as light rail transit, but it operates more like a streetcar and is identified as a streetcar in the NTD. 


\section{Tampa}

Tampa's TECO streetcar line, opened in 2002, connects the historic Ybor City neighborhood with a number of other tourist-focused destinations (Convention Center, Channelside) in the downtown area (TECO Line Streetcar System 2012). The vehicles operate in segregated rights-of-way on city streets. The streetcar's late hours of operation make this a non-commuter-oriented, tourist-focused operation.

\section{Basic Streetcar Operating and Service Characteristics}

Table 1 reports basic streetcar operating and service statistics for the seven cities. The seven streetcar systems are either operated directly or under contract by the primary transit agency in each city. Five of the seven streetcars have opened since 2001, with New Orleans having the oldest system, dating back to the late 19th century. Most of the streetcar alignments are short, with Memphis and New Orleans having longer alignments because they operate multiple streetcar lines. Streetcar operating speeds (vehicle revenue miles divided by vehicle revenue hours, or miles per hour during revenue service) are generally slow, with the highest speeds found in Tacoma, Memphis, New Orleans, and Portland. All of the streetcars operate at speeds slower than the average motor bus in the local transit system, with most streetcar speeds less than half the average bus speed (the slowest bus speeds among the seven cities are in Portland, with an average of 11.8 miles per hour, calculated as total bus revenue miles divided by total bus revenue hours) (FTA 2012). The various streetcar lines have a wide variation in the number of stops, with stop spacing ranging between 0.10 miles and 0.25 miles across the seven cities, but there appears to be little correlation between stop spacing and operating speeds. The two cities with the closest stop spacing (Portland and New Orleans) are not the cities with the slowest streetcars; instead, they rank third and fourth fastest among the seven streetcar cities.

The streetcar fares in Seattle and Tampa are higher than the regular bus fares, while the fares in Little Rock and Memphis are lower than the regular bus fare. The fares in Portland and New Orleans are identical to the bus fare. Prior to September 1, 2012, Portland operated a fare-free zone on its streetcars in the downtown; thus, the statistical data on ridership and service reflect the earlier period with the farefree zone in place. The streetcar in Tacoma, Tacoma Link, still operates fare-free service. In addition to operating within the downtown, this streetcar serves as a feeder to longer-distance bus and rail transit services that operate under a zonal fare system based on trip distance. 


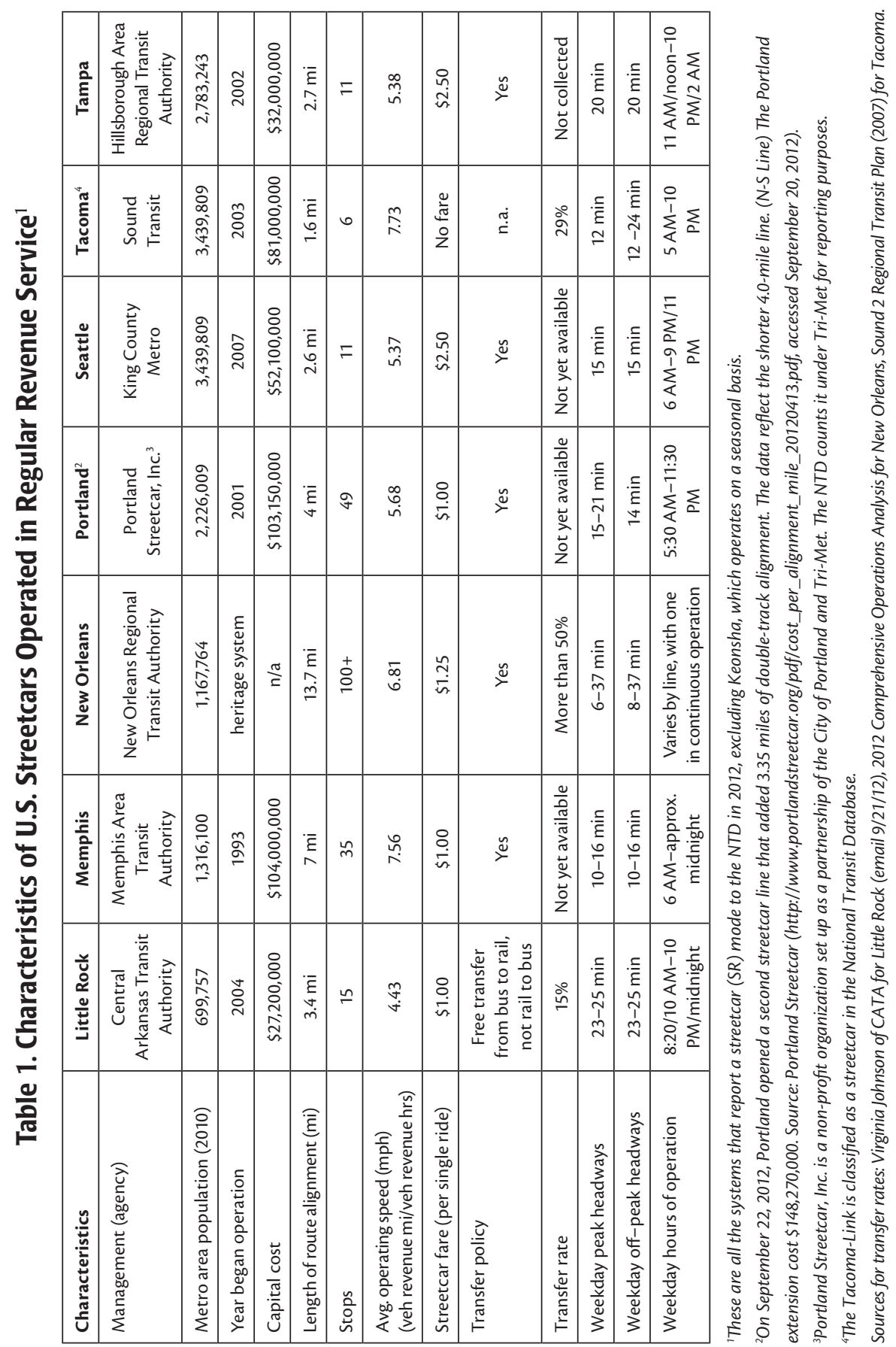


Transfer policies reflect the agency's view of the streetcar's role in the larger transit system, in terms of whether it is viewed as a stand-alone service, as an integrated piece of the transit network, or something in between. Five of the seven cities permit fare-free transfers in either direction between bus and streetcar, while one city (Little Rock) allows bus riders (who pay a higher fare per ride) to transfer free to the streetcar but requires streetcar riders to pay an additional fare to use the bus. Tacoma's streetcar is fare-free, so riders pay a fare when transferring to another transit service.

Transfer rates reflect the way riders actually use the streetcar in the context of the larger transit system, with higher transfer rates indicative of more service integration between the streetcars and the other transit modes. Differences in transfer rates correspond roughly to differences in the transfer policy. The highest reported transfer rates are found in New Orleans, which allows fare-free transfers across its transit modes, while the lowest reported transfer rates are found in Little Rock, which permits them in only one direction, from bus to streetcar. The other streetcars that function primarily as downtown circulators have reported transfer rates in between these two values. The fact that some systems, such as Hillsborough Area Regional Transit Authority in Tampa, do not even track transfer activity between the streetcar and other modes indicates that the agency does not view the streetcar as an integral part of its regular transit service. Streetcar headways and hours of operation are roughly comparable to those of the buses operated in the same geographic areas in each of the seven cities, with the exceptions of the Little Rock and Tampa, streetcars which begin service much later in the morning than the regular bus system.

\section{Key Performance Indicators}

Selected several key performance indicators were selected for gauging the performances of streetcars as modes of public transportation within their respective transit systems. The transfer rates noted earlier were one key measure of service integration, and operating speed is also a key service characteristic. The other key performance indicators include ridership, service, operating cost, and performance ratios such as ridership per unit of service (service productivity) and operating cost per ride (cost effectiveness). For ridership, both unlinked passenger trips (or boardings) and passenger miles were considered, when and where available. For service, both vehicle revenue hours and vehicle revenue miles were considered. For operating expense, total operating expense for the streetcar mode was included as defined in the NTD (FTA 2012). Finally, NTD variables were used to calculate the 
streetcar's share of total transit agency ridership and service to get a sense of the streetcar mode's relative importance in the transit agency's overall service delivery.

These basic ridership, service, and cost data are available from the NTD for six of the agencies (FTA 2012; Florida Department of Transportation 2012). Prior to 2012, streetcar statistics were reported as part of the light rail mode in the NTD. For six of the seven cities, the streetcar would have been the only rail service reported under this mode code, so it is safe to assume that these statistics in the NTD referred to the streetcar and not another rail service. For the seventh city, Portland Streetcar, Inc., provided streetcar ridership and service data from 2008-2010, and for operating expense in 2010 (Portland Streetcar, Inc. 2012b; Portland Streetcar, Inc. 2012c). Due to the lack of operating expense data for other years from Portland, only 2010 operating cost data were considered in the study. Ridership data on a passenger mile basis were unavailable for Portland's streetcar, hence its non- availability designation $(\mathrm{n} / \mathrm{a})$ in the relevant tables.

Tables 2, 3, and 4 report ridership statistics for the seven streetcar cities from 2008 until the most recent full reporting year. Table 2 shows that New Orleans, Seattle, and Tacoma have seen streetcar boardings increase in recent years, whereas Portland and Memphis have been relatively stable and Little Rock and Tampa have seen decreases. Table 3 reports ridership in terms of passenger miles, which gauges the length of passenger trip-making on the streetcar mode, and Table 4 reports average trip distances (passenger miles per unlinked passenger trip). The data in tables 3 and 4 are reported from 2008 to 2010, the last year for which passenger mile data are consistently available on a modal basis in the NTD. The key table here is Table 4 , which indicates significant differences in the trip lengths served by the different streetcars. Much of this variability can be explained by differences in system extent and stop spacing, but some of the difference is also a function of the different ways that riders use these streetcars. The longer average trip lengths in New Orleans are indicative of a streetcar system that is used more like an LRT system, serving longdistance trips and indeed functioning as something like a transit system backbone (as is discussed later), while the short trip lengths in Seattle and Memphis point to the mode's primary function as a downtown circulator mode or connector serving very short-distance trips. Because New Orleans is the oldest of the streetcar systems, with a pre-modern era streetcar network, it differs in many important respects from its modern peers. 
Table 2. Annual Ridership (Unlinked Passenger Trips) on U.S. Streetcars Operated in Regular Revenue Service (2008-2011)

\begin{tabular}{|l|c|c|c|c|}
\hline City & $\mathbf{2 0 0 8}$ & $\mathbf{2 0 0 9}$ & $\mathbf{2 0 1 0}$ & $\mathbf{2 0 1 1}$ \\
\hline Little Rock & 112,578 & 120,057 & 107,079 & 100,402 \\
\hline Memphis & $1,060,410$ & $1,158,904$ & $1,092,605$ & $1,157,425$ \\
\hline New Orleans & $4,708,139$ & $4,715,163$ & $5,931,758$ & $6,602,396$ \\
\hline Portland & $3,880,079$ & $3,785,553$ & $3,950,860$ & $3,838,398$ \\
\hline Seattle & 413,937 & 451,204 & 520,932 & 715,043 \\
\hline Tacoma & 930,632 & 887,061 & 869,076 & 973,936 \\
\hline Tampa & 455,940 & 466,536 & 479,967 & 386,423 \\
\hline
\end{tabular}

Source: Summed from NTD Monthly Adjusted Data Tables, http://www. ntdprogram.gov/ntdprogram/data.htm (accessed September 20, 2012).

Table 3. Passenger Miles on U.S. Streetcars in Regular Revenue Service (2008-2010)

\begin{tabular}{|l|r|r|r|}
\hline City & \multicolumn{1}{|c|}{$\mathbf{2 0 0 8}$} & \multicolumn{1}{c|}{$\mathbf{2 0 0 9}$} & \multicolumn{1}{c|}{$\mathbf{2 0 1 0}$} \\
\hline Little Rock & 206,572 & 183,751 & 165,718 \\
\hline Memphis & 820,185 & 940,028 & 917,815 \\
\hline New Orleans & $8,223,507$ & $12,303,585$ & $15,384,381$ \\
\hline Portland & $\mathrm{n} / \mathrm{a}$ & $\mathrm{n} / \mathrm{a}$ & $\mathrm{n} / \mathrm{a}$ \\
\hline Seattle & 378,221 & 414,617 & 471,587 \\
\hline Tacoma & 919,371 & 880,476 & 871,189 \\
\hline Tampa & 728,890 & 776,734 & 789,244 \\
\hline
\end{tabular}

Source: FTIS extraction from NTD, www.ftis.org (accessed September 20, 2012).

Table 4. Average Trip Length (miles) on U.S. Streetcars in Regular Revenue Service (2008-2010)

\begin{tabular}{|l|c|c|c|}
\hline City & $\mathbf{2 0 0 8}$ & $\mathbf{2 0 0 9}$ & $\mathbf{2 0 1 0}$ \\
\hline Little Rock & 1.83 & 1.53 & 1.55 \\
\hline Memphis & 0.77 & 0.81 & 0.84 \\
\hline New Orleans & 1.75 & 2.61 & 2.59 \\
\hline Portland & n/a & n/a & n/a \\
\hline Seattle & 0.91 & 0.92 & 0.91 \\
\hline Tacoma & 0.99 & 0.99 & 1.00 \\
\hline Tampa & 1.60 & 1.66 & 1.64 \\
\hline
\end{tabular}


Table 5 reports the streetcar revenue hours and revenue miles of service operated in each city from 2008 to 2011. The table shows that the amount of service being operated has either been stable or in modest decline in most cities. Little Rock, New Orleans, and Seattle offered more service in 2011 than they provided in 2008, but, in two of those three cases, the amount of service they provided was less in 2011 than it was in 2010. Thus, it is difficult to detect any trend related to the amount of service provided. Table 5. Annual Service on U.S. Streetcars Operated in
Regular Revenue Service (2008-2011)

\begin{tabular}{|c|c|c|c|c|}
\hline City & 2008 & 2009 & 2010 & 2011 \\
\hline \multicolumn{5}{|c|}{ Vehicle Revenue Miles } \\
\hline Little Rock & 38,381 & 37,696 & 52,687 & 42,063 \\
\hline Memphis & 412,765 & 362,410 & 298,763 & 294,536 \\
\hline New Orleans & 756,815 & 816,890 & 947,790 & 926,132 \\
\hline Portland & 216,308 & 210,362 & 173,714 & 170,530 \\
\hline Seattle & 56,904 & 60,150 & 59,964 & 61,727 \\
\hline Tacoma & 94,189 & 89,427 & 90,195 & 82,565 \\
\hline Tampa & 80,045 & 73,114 & 71,067 & 74,714 \\
\hline \multicolumn{5}{|c|}{ Vehicle Revenue Hours } \\
\hline Little Rock & 8,669 & 8,481 & 11,904 & 9,471 \\
\hline Memphis & 59,210 & 56,790 & 48,797 & 39,612 \\
\hline New Orleans & 94,461 & 102,439 & 122,586 & 127,472 \\
\hline Portland & 38,047 & 37,001 & 30,555 & 29,995 \\
\hline Seattle & 11,077 & 11,207 & 11,174 & 11,509 \\
\hline Tacoma & 9,708 & 9,424 & 9,727 & 9,818 \\
\hline Tampa & 15,713 & 14,246 & 13,805 & 14,077 \\
\hline
\end{tabular}

Source (all except Portland): Summed from National Transit Database Monthly Adjusted Data Tables. http://www.ntdprogram.gov/ntdprogram/data.htm (accessed September 20, 2012). Source (Portland): Benchmark Reliability Reports obtained from Portland Streetcar, Inc.

Table 6 reports the ridership associated with each hour or mile of service provided by the streetcar mode, from 2008 through 2011. This table is, thus, the first of the reported service performance, or service productivity, measures. Using the number of unlinked passenger trips per revenue mile (the upper panel of the table) as a performance indicator, the table indicates improved or stable service productiv- 
ity from 2008 through the end of 2011 everywhere except Little Rock and Tampa. Using the number of unlinked passenger trips per revenue hour (the bottom panel of the table) as a performance indicator, and looking over the period from 2008 to 2011, the last complete year for which data are available, the table indicates increased service productivity in Memphis, Portland, and Seattle, whereas productivity has been relatively flat elsewhere. The biggest increase in productivity has occurred in Memphis (86\% increase on a trips per mile basis and more than 100\% increase on a trips per hour basis); Seattle has experienced a 60 percent increase in both of these productivity indicators. Service productivity increased in four other cities, at a more modest level, over the same time period, while service productivity actually declined in Tampa.

Table 6. Service Productivity on U.S. Streetcars in Regular Revenue Service (2008-2011)

\begin{tabular}{|l|r|r|r|r|}
\hline City & $\mathbf{2 0 0 8}$ & $\mathbf{2 0 0 9}$ & $\mathbf{2 0 1 0}$ & $\mathbf{2 0 1 1}$ \\
\hline Unlinked Passenger Trips per Vehicle Revenue Mile \\
\hline Little Rock & 2.93 & 3.18 & 2.03 & 2.39 \\
\hline Memphis & 2.57 & 3.20 & 3.66 & 3.93 \\
\hline New Orleans & 6.22 & 5.77 & 6.26 & 7.13 \\
\hline Portland & 17.94 & 18.00 & 22.74 & 22.51 \\
\hline Seattle & 7.27 & 7.50 & 8.69 & 11.58 \\
\hline Tacoma & 9.88 & 9.92 & 9.64 & 11.80 \\
\hline Tampa & 5.70 & 6.38 & 6.75 & 5.17 \\
\hline Unlinked Passenger Trips per Vehicle Revenue Hour \\
\hline Little Rock & 12.99 & 14.16 & 9.00 & 10.60 \\
\hline Memphis & 17.91 & 20.41 & 22.39 & 29.22 \\
\hline New Orleans & 49.84 & 46.03 & 48.39 & 51.79 \\
\hline Portland & 101.98 & 102.31 & 129.30 & 127.97 \\
\hline Seattle & 37.37 & 40.26 & 46.62 & 62.13 \\
\hline Tacoma & 95.86 & 94.13 & 89.35 & 99.20 \\
\hline Tampa & 29.02 & 32.75 & 34.77 & 27.45 \\
\hline
\end{tabular}

A third service productivity is the load factor, or number of passenger miles per vehicle revenue mile. This indicator can be interpreted as the average number of passengers on a transit vehicle at a particular moment in time. Because passenger miles data are complete only through the end of 2010, the data presented in 
Table 7 cover 2008-2010. Table 7 shows wide variation in load factor across the seven cities, with the highest values in New Orleans and Tampa, where streetcar riders tend to take longer trips, as noted earlier. The lowest load factors are found in Memphis and Little Rock, where average trip distances are relatively short and there are smaller numbers of trips per hour or per mile being carried on the streetcar. In both of these cases, there is significant excess passenger capacity on the streetcar lines. By contrast, streetcars in New Orleans are quite full, on average. The differences in load factors across the seven cities are, at least partially, due to the different urban settings in which the streetcars operate. New Orleans is a denser, more traditional urban environment with a larger transit-dependent population than the other cities, but the different roles the streetcar plays in these various cities - with the streetcars in New Orleans being better integrated with local bus services and operating at higher than average streetcar speedsare undoubtedly also important explanations for the variation in load factor.

\section{Table 7. Load Factor (Passenger Mile per Vehicle Revenue Mile) on U.S. Streetcars in Regular Revenue Service (2008-2010)}

\begin{tabular}{|l|r|r|r|}
\hline City & \multicolumn{1}{|c|}{$\mathbf{2 0 0 8}$} & $\mathbf{2 0 0 9}$ & $\mathbf{2 0 1 0}$ \\
\hline Little Rock & 5.38 & 4.87 & 3.15 \\
\hline Memphis & 1.99 & 2.59 & 3.07 \\
\hline New Orleans & 10.87 & 15.06 & 16.23 \\
\hline Portland & $\mathrm{n} / \mathrm{a}$ & $\mathrm{n} / \mathrm{a}$ & $\mathrm{n} / \mathrm{a}$ \\
\hline Seattle & 6.65 & 6.89 & 7.86 \\
\hline Tacoma & 9.76 & 9.85 & 9.66 \\
\hline Tampa & 9.11 & 10.62 & 11.11 \\
\hline
\end{tabular}

Table 8 reports streetcar operating expenses (in inflation-adjusted 2011 dollars) for both the modal total and on a per-unlinked-passenger-trip and per-passenger-mile basis for 2010, the most recent year for which data are available for the seven cases. The latter measures are the more instructive ones from a service performance perspective, because they are cost-effectiveness measures. The table indicates considerable variation in operating cost per unlinked passenger trip (UPT), with Portland at the low end and Tampa and Little Rock at the high end of the range. Streetcar service is much more cost-effective as a public transportation mode, on a per-trip basis, in Portland than in Tampa and Little Rock. The higher numbers of boardings per unit of service explain part of these differences in operating cost per passenger, 
but so do differences in cost levels across the various cities. In 2010, operating cost per revenue hour (total operating cost divided by vehicle revenue hours) for the seven cities ranged from a low of $\$ 86$ per hour in Little Rock to a high of $\$ 208$ per hour in Seattle, although expressed on a per-revenue-mile basis (total operating cost divided by vehicle revenue miles), the ranges were from a low of $\$ 14$ per mile in Memphis to \$34 per mile in Tampa.

By comparison, operating cost per passenger trip by motor bus in the seven systems ranges from $\$ 3.95$ per unlinked passenger trip in Portland to $\$ 7.29$ per unlinked passenger trip in Tacoma, due to longer average trip lengths (Florida Department of Transportation 2012). In two cities (Little Rock and Tampa), streetcar operating costs per trip are higher than bus operating costs ( $\$ 4.29$ in Little Rock and $\$ 4.63$ in Tampa, in 2010), whereas in the other cities the streetcar operating costs per trip are lower than the bus costs per trip.

\section{Table 8. Operating Expense on U.S. Streetcars in Regular Revenue Service, 2010 (2011 dollars)}

\begin{tabular}{|l|c|c|c|}
\hline \multirow{2}{*}{\multicolumn{1}{|c|}{ City }} & Total & Per UPT & Per Pass. Mile \\
\cline { 2 - 4 } & 2010 & 2010 & 2010 \\
\hline Little Rock & $\$ 1,024,033$ & $\$ 9.56$ & $\$ 6.18$ \\
\hline Memphis & $\$ 4,208,069$ & $\$ 3.85$ & $\$ 4.58$ \\
\hline New Orleans & $\$ 24,248,078$ & $\$ 4.09$ & $\$ 1.58$ \\
\hline Portland & $\$ 5,500,000$ & $\$ 1.39$ & $\mathrm{n} / \mathrm{a}$ \\
\hline Seattle & $\$ 2,318,808$ & $\$ 4.45$ & $\$ 4.92$ \\
\hline Tacoma & $\$ 3,150,604$ & $\$ 3.63$ & $\$ 3.62$ \\
\hline Tampa & $\$ 2,583,860$ & $\$ 5.38$ & $\$ 3.27$ \\
\hline
\end{tabular}

Source: FTIS extraction from NTD (inflation adjusted 2011 dollars), www.ftis.org. Portland Data from Portland Streetcar, Inc.

The table reports operating expense on a per-passenger-mile basis for the six cities for which passenger mile data are available, with variability reflecting both differences in average trip lengths and differences in service costs. The per-passengermile costs for all the streetcar systems are significantly higher than their bus counterparts for the most recent available year (2010). While the streetcar operating costs per passenger mile range from $\$ 1.58$ to $\$ 6.18$ per passenger mile-a large range-bus operating costs per passenger mile in 2010 ranged from $\$ .78$ per passenger mile (Memphis) to $\$ 1.65$ per passenger mile (New Orleans), a much narrower range (Florida Department of Transportation 2012). 
The final pair of tables show streetcar service operated by each agency within the total transit ridership and service accounted for on all of the agency's fixed-route modes. Table 9 examines ridership, on both an unlinked-passenger-trip and a perpassenger-mile basis. The table shows that the streetcar in New Orleans functions as an integral part of the system, carrying more than 40 percent of passenger trips and more than 30 percent of passenger miles carried by the transit system as a whole. The other streetcar systems are much more modest contributors to overall ridership. Table 10 provides the same type of comparison, but instead reports the amount of service provided. New Orleans and Memphis stand out in the group of cities as cases where a significant amount of agency service is provided on the streetcar lines. A quick comparison of the two tables, looking specifically at passenger trips contrasted with revenue hours, shows that all of the streetcar systems, except that in Little Rock, account for a larger percentage of trips than they do of service hours, suggesting that the agencies are gaining some operational efficiency through the deployment of streetcar service, at least in terms of passenger carriage per unit of service.

Table 9. Streetcar Ridership as a Share of Total Agency Fixed-Route Ridership (2007-2011)

\begin{tabular}{|c|c|c|c|c|c|}
\hline \multicolumn{6}{|c|}{ Unlinked Passenger Trips } \\
\hline City & 2007 & 2008 & 2009 & 2010 & 2011 \\
\hline Little Rock & $5.6 \%$ & $4.3 \%$ & $4.9 \%$ & $4.3 \%$ & $3.7 \%$ \\
\hline Memphis & $9.4 \%$ & $9.2 \%$ & $10.2 \%$ & $9.9 \%$ & $11.4 \%$ \\
\hline New Orleans & $18.0 \%$ & $41.8 \%$ & $41.5 \%$ & $43.4 \%$ & $42.6 \%$ \\
\hline Portland & $3.4 \%$ & $3.6 \%$ & $3.7 \%$ & $3.7 \%$ & $3.5 \%$ \\
\hline Seattle & $\mathrm{n} / \mathrm{a}$ & $0.3 \%$ & $0.4 \%$ & $0.5 \%$ & $0.6 \%$ \\
\hline Tacoma & $6.7 \%$ & $5.8 \%$ & $4.7 \%$ & $3.8 \%$ & $3.9 \%$ \\
\hline Tampa & $4.5 \%$ & $3.3 \%$ & $3.8 \%$ & $3.5 \%$ & $2.6 \%$ \\
\hline \multicolumn{5}{|c|}{ Passenger Miles } & \\
\hline Little Rock & $2.9 \%$ & $1.5 \%$ & $1.4 \%$ & $1.3 \%$ & \\
\hline Memphis & $1.4 \%$ & $1.5 \%$ & $1.7 \%$ & $1.7 \%$ & \\
\hline New Orleans & $7.6 \%$ & $27.0 \%$ & $30.2 \%$ & $32.6 \%$ & \\
\hline Portland & $0.0 \%$ & $0.0 \%$ & $0.0 \%$ & $0.0 \%$ & \\
\hline Seattle & $\mathrm{n} / \mathrm{a}$ & $0.1 \%$ & $0.1 \%$ & $0.1 \%$ & \\
\hline Tacoma & $0.4 \%$ & $0.9 \%$ & $0.3 \%$ & $0.3 \%$ & \\
\hline Tampa & $1.3 \%$ & $1.0 \%$ & $1.1 \%$ & $1.2 \%$ & \\
\hline
\end{tabular}

Source: FTA 2012. Note: Fixed Route includes all bus and rail modes, but excludes demand response and vanpool services. 
Table 10. Streetcar Service as a Share of Total Agency Fixed-Route Service (2007-2011)

\begin{tabular}{|l|c|c|c|c|c|}
\hline \multicolumn{7}{|c|}{ Vehicle Revenue Miles } \\
\hline City & 2007 & 2008 & 2009 & 2010 & 2011 \\
\hline Little Rock & $1.9 \%$ & $1.7 \%$ & $1.6 \%$ & $2.3 \%$ & $1.8 \%$ \\
\hline Memphis & $6.4 \%$ & $6.2 \%$ & $5.6 \%$ & $4.7 \%$ & $4.8 \%$ \\
\hline New Orleans & $6.3 \%$ & $19.8 \%$ & $18.1 \%$ & $20.2 \%$ & $19.4 \%$ \\
\hline Portland & $0.0 \%$ & $0.0 \%$ & $0.0 \%$ & $0.0 \%$ & $0.0 \%$ \\
\hline Seattle & $\mathrm{n} / \mathrm{a}$ & $0.2 \%$ & $0.2 \%$ & $0.2 \%$ & $0.2 \%$ \\
\hline Tacoma & $0.9 \%$ & $0.8 \%$ & $0.7 \%$ & $0.6 \%$ & $0.5 \%$ \\
\hline Tampa & $1.1 \%$ & $1.1 \%$ & $1.0 \%$ & $0.9 \%$ & $1.0 \%$ \\
\hline \multicolumn{7}{|c|}{ Vehicle Revenue Hours } & & & \\
\hline Little Rock & $5.9 \%$ & $5.2 \%$ & $5.1 \%$ & $7.0 \%$ & $5.6 \%$ \\
\hline Memphis & $13.3 \%$ & $12.6 \%$ & $12.0 \%$ & $10.9 \%$ & $9.8 \%$ \\
\hline New Orleans & $11.7 \%$ & $27.6 \%$ & $27.2 \%$ & $29.7 \%$ & $29.7 \%$ \\
\hline Portland & $1.8 \%$ & $1.9 \%$ & $1.8 \%$ & $1.3 \%$ & $1.3 \%$ \\
\hline Seattle & $\mathrm{n} / \mathrm{a}$ & $0.4 \%$ & $0.4 \%$ & $0.4 \%$ & $0.4 \%$ \\
\hline Tacoma & $1.9 \%$ & $1.8 \%$ & $1.5 \%$ & $1.3 \%$ & $1.3 \%$ \\
\hline Tampa & $2.9 \%$ & $2.7 \%$ & $2.4 \%$ & $2.2 \%$ & $2.4 \%$ \\
\hline
\end{tabular}

Source: FTA 2012. Note: Fixed-route includes all bus and rail modes, but excludes demand response and vanpool services.

\section{Conclusion}

This descriptive overview provided some basic insights into how streetcars are functioning and performing in terms of their role as public transportation modes in seven U.S. cities. There is significant variation in performance, with some of this variation a function of the built environment within which the systems operate and/or of the degree of integration with the rest of the transit system, captured in the transfer rates. In all of the cases, the streetcars are not operating faster than the agency's typical motor buses in revenue service, although they are providing service that riders value, as reflected by the higher numbers of trips served per hour of service, particularly in Portland, Tacoma, Seattle, and New Orleans. This is not to say that in all of the four more successful cases the streetcars are necessarily better transit investments than regular buses, higher quality buses, or a different type of rail service. This analysis did not consider the capital expenses of these invest- 
ments, which are significant and exceed those related to bus transit service. Future research is needed to address these significant questions.

The difficulty encountered in obtaining data on streetcar service from many of the agencies in this study suggests that many do not really view the streetcars as primarily transit service but instead view them more as development catalysts or as devices used to serve tourists and shoppers as opposed to regular transit riders. Whether this is an effective strategy or not is also something beyond the scope of this study, but it is indicative of a dilemma in these fiscally-constrained times, given that streetcar projects funded by the federal government's resource-strapped capital grants program use resources that might have been used for other projects designed primarily to transport regular transit riders. Future research is clearly needed to consider these and other resource apportionment decisions in terms of their equity and effectiveness as alternative public transportation investment strategies. Streetcars might make sense to a local community as part of a tourist development or economic development strategy, but, if so defined, they should probably not be funded principally from transit funds. At a minimum, better data collection is needed to permit a more informed evaluation of the performance of these public transit investments. Promoters of these investments should also be clear about the relative importance of the transit and non-transportation roles these investments are designed to play.

\section{Acknowledgments}

The author wishes to thank the following individuals at the transit agencies examined in this paper for their invaluable assistance in providing agency data and documents: Carol Cooper, Rob Coughlin, Kay Dannen, Lynn Dupont, Steve Feigenbaum, Virginia Johnson, John Lancaster, Stefan Marks, Jason Sappington, and Betty Wineland.

\section{References}

Central Arkansas Transit Authority. 2012. River Rail, http://www.cat.org/rrail/ (accessed September 20, 2012).

Federal Transit Administration. 2012. National Transit Database Monthly Adjusted Data through July 2012. Available at http://www.ntdprogram.gov/ntdprogram/data.htm (accessed September 20, 2012). 
Florida Department of Transportation. 2012. Florida Transit Information System: INTDAS Tool. Available at http://www.ftis.org (accessed September 20, 2012).

Hovee, Eric, and Rick Gustafson. 2012. Streetcar-development linkage: The Portland Streetcar loop. E. D. Hovee and Company and Shiels Obletz Johnsen, Inc.

Memphis Area Transit Authority. 2012. Trolley Service. http://www.matatransit.com/trolleyService.aspx (accessed September 20, 2012)

Nelson/Nygaard Consulting Associates. 2012. (New Orleans) Regional Planning Commission Comprehensive Operations Analysis. Obtained from New Orleans Regional Planning Commission (NORPC) at http://www.norpc.org/ public_transportation.html (accessed September 19, 2012).

New Orleans Regional Transportation Authority.2012.StreetcarSchedulesandMaps. http://www.norta.com/Maps_Schedules/StreetCar/index.html (accessed September 20, 2012).

O'Toole, Randall. 2012. The great streetcar conspiracy. Policy Analysis No. 699, Cato Institute, Washington, DC.

Portland Streetcar, Inc. 2012a. Route Map and Schedule. http://portlandstreetcar. org/pdf/map_printable5.pdf (accessed September 20, 2012).

Portland Streetcar, Inc. 2012b. Service benchmark reliability reports, FY 06/07-FY 11/12. Obtained from Carol Cooper, Portland Streetcar, Inc., via email September 25, 2012.

Portland Streetcar, Inc. 2012c. Ridership counts, July 2001-June 2012. Obtained from Carol Cooper, Portland Streetcar, Inc.m via email September 26, 2012.

Scheib, Samuel. 2012. The streetcar swindle. Reason Magazine, October 2012.

Seattle Streetcar. 2012. South Lake Union Streetcar Line. http://www.seattlestreetcar.org/slu.htm (accessed September 20, 2012).

Smatlak, John. 2012. U.S. Streetcar Systems. http://www.railwaypreservation.com/ vintagetrolley/trolleylist.htm (accessed September 18, 2012).

Sound Transit. 2007. Sound Transit 2 Regional Transit Plan. Appendix C: Benefits, costs, revenues, capacity, and reliability. http://www.soundtransit.org/Documents/pdf/st2/Appd_C_08_07.pdf (accessed September 18, 2012).

Sound Transit. 2012. Tacoma Link. http://www.soundtransit.org/Schedules/ Tacoma-Light-Link-Rail.xml (accessed September 20, 2012). 
TECO Line Streetcar System. 2012. About. http://www.tecolinestreetcar.org/ (accessed September 15, 2012).

Transit Alternatives Studio Members. 2011. Tennessee street corridor transit alternatives criteria study: A vision for an enhanced transit application in Tallahassee. Prepared for StarMetro by Florida State University Department of Urban and Regional Planning.

Transit Cooperative Research Program. 2010. Relationships between streetcars and the built environment-A synthesis of transit practice. Transportation Research Board of The National Academies, Washington, DC.

\section{About the Author}

JefrRey BRown (jrbrown3@fsu.edu) is an Associate Professor in the Department of Urban and Regional Planning at Florida State University. 